\title{
Social Exclusion in the Process of Employment: The Experiences of Roma Youth
}

\author{
Ali Egi \\ Çankırı Karatekin University, Çankırı, TURKEY \\ Department of Sociology
}

Received: 14 March 2020 • Accepted: 28 May 2020 • Published Online: 20 July 2020

\begin{abstract}
This study aims to understand how young individuals in the Roma/Gypsy community experience the social exclusion in the employment process. This has been structured according to the qualitative research design based on experience, meaning, and processes. In-depth interviews and a focus group were conducted with 11 Roma youths aged 19-30 living in Balıkesir, Turkey. A semi-structured interview form was used for the interviews. The findings were analyzed by using a phenomenological approach. The findings are clustered on the basis of identity, space and employment: (1) The Roma youth are exposed to social exclusion due to their ethnic identity during the employment process and are therefore forced to work in temporary jobs. (2) The young Roma experience social exclusion, especially in job applications. (3) The Roma identity and the stigmatized neighborhoods associated with this identity lead to problems for Roma youth in job applications or working life. (4) The attitudes of Roma youth oriented social exclusion in employment vary according to the level of education. Finally, (5) It has been discovered that the relationship established by Roma youth with their neighborhoods has a three-dimensional character: "normalization, self-criticism and divergence".
\end{abstract}

Keywords: Roma/Gypsy, Roma youth, employment, Roma youth and employment, social exclusion, spatial stigmatization, Turkey.

\section{Introduction}

Roma or Gypsies ${ }^{1}$ have been constantly exposed to discrimination and social exclusion in the regions they live in. Although naming ${ }^{2}$ has varied in different geographies (Kolukırık, 2004: 8-13), attitudes of the rest of society towards Roma have remained considerably unaltered. As a reflection of these attitudes in modern society, Roma communities have squeezed into stigmatized areas of cities and thus became marginalized. The Roma community, on which poverty is wandering like a specter, is trying to cope with the difficulties of material living conditions. They also struggle with the social superstitions that developed because of their ethnic identity. There is a discriminatory and internalized discourse on the Roma community in social life. The discourse

${ }^{1}$ Young Roma participants who considered that the term "Gypsy" had a pejorative meaning, preferred the use of "Roma", which means "human" or "man" in the Romani language (Kenrick, 2007: 215) during the research.

2 Rom, Dom, Lom, Poşa, Abdal, Elekçi, Koçer, Kıpti, Cono, Cingen, Mitrıp, etc.

(C) Authors. Terms and conditions of Creative Commons Attribution 4.0 International (CC BY 4.0) apply. Correspondence: Ali Egi, Çankırı Karatekin University, Department of Sociology, Çankırı, TURKEY. Email: aliegi86@gmail.com. 
legitimates the processes of exclusion and stigmatization. It is also the source of structural social problems. Roma living in cities struggle with the concrete situations of these problems. The main problems and policies are clustered in education, housing, health, and employment categories (Aile, Çalışma ve Sosyal Hizmetler Bakanlığı, 2016).

This study, which is designed as a qualitative research, remarks specifically on the exclusion experiences of young Roma 3 in the employment process. It basically seeks to understand the following research question in terms of the phenomenological approach: How do Roma youth experience social exclusion in the employment process? The purpose of the study is to explore the social patterns of the point of view along with the strategies of Roma youth who are exposed to exclusion in employment. Employment is a critical phase in the social life of Roma individuals because it provides a public sphere where Roma can struggle with exclusion and stigmatization.

Roma/Gypsy studies in Turkey seem to be clustered into three categories; ethnicity [identification, culture, history] (Aksu, 2010; Aras, 2016; Şanlıer, 2013), discrimination [social exclusion, stigmatization, inequality, legal struggle on fundamental rights] (Taylan \& Barış, 2015; Gezgin, 2016; Karan, 2017; Marsh, 2008) and social policy [poverty, disadvantageous, access to services, education, health, housing, employment] (Akkan, Deniz, \& Ertan, 2011; Gün, 2016). There have also been comprehensive reports regarding all of these categories prepared by public institutions and non-governmental organizations (Batı Karadeniz Kalkınma Ajansı, 2016; Genç \& Taylan, 2017; İlik, 2016; Taylan, Barış \& Genç, 2015). Among this literature, it has encountered no studies that especially investigate or try to figure out the employment process of Roma youth. The paper tries to explore what the young Roma in Balıkesir experience during their participation in employment, and what their ethnic identity means in employment. Thus, the study is methodologically limited, but it is significant in terms of describing what ethnic identity means in employment for a young Roma with an underprivileged chance of life.

\section{Research method}

\subsection{Research model}

This study uses a qualitative phenomenological approach to understand the social exclusion experiences of Roma youth in the employment process. Phenomenological research, which is formed around a main phenomenon, focuses on what people experience and how they interpret this experience (Patton, 2002: 106). Therefore, the phenomenological approach is based on the perspective of individuals. The main phenomenon in this study is the "social exclusion" fact that emerged during the employment process. It is trying to be understood with the phenomenological model, how the main phenomenon is interpreted in the social world of Roma youth within the framework of identity and space.

\subsection{Participant group}

Within the scope of the study, it was planned to reach young people between the ages of 19-30 who live in a place called the "Roma/Gypsy" neighborhood. Participants were selected from Roma youth working in either a temporary or regular job. Interviews were conducted with the participants through the mediation of opinion leaders living in the neighborhood. In order to ensure that individuals' multiple perspectives are reflected (Creswell, 2012: 207), participants were determined according to the maximum diversity type of purposeful sampling. In-depth interviews were conducted with 11 young people (7 males, 4 females) living in Gümüşçeşme,

3 Throughout this paper, both the terms "Roma youth" and "the young Roma" will be refer to individuals between the ages of 11-30 in the Roma community living in Balıkesir. 
Gündoğan and Dinkçiler neighborhoods of Balıkesir. The age, education and occupational information of the participants are shown in the table below:

Chart 1. Young participants (P) profile

\begin{tabular}{|c|c|c|l|l||l|l|l|l|l|}
\hline Gender & ID & Age & Education & Occupation & Gender & ID & Age & Education & Occupation \\
\hline Male & P1 & 29 & ESG & $\begin{array}{l}\text { Musician } \\
\text { (oldest) }\end{array}$ & Male & P7 & 28 & ESG & Hairdresser \\
\hline Male & P2 & 22 & $\begin{array}{l}\text { No } \\
\text { education }\end{array}$ & Junk-dealer & Female & P8 & 21 & PSG & $\begin{array}{l}\text { Cashier } \\
\text { (youngest) }\end{array}$ \\
\hline Male & P3 & 23 & HSG & $\begin{array}{l}\text { Security } \\
\text { guard }\end{array}$ & Female & P9 & 25 & PSG & Cleaner \\
\hline Male & P4 & 24 & HSG & $\begin{array}{l}\text { Bazaar } \\
\text { worker }\end{array}$ & Female & P10 & 24 & PSG & $\begin{array}{l}\text { Broom } \\
\text { making }\end{array}$ \\
\hline Male & P5 & 24 & HSG & $\begin{array}{l}\text { Municipal } \\
\text { employee }\end{array}$ & Female & P11 & 22 & Undergraduate & Student \\
\hline Male & P6 & 26 & ESG & Chef & & & & & \\
\hline PSG: Primary school graduate ESG: Elementary school \\
graduate
\end{tabular}

In the findings section, $\mathrm{P}(1-11)$ ID codes were used instead of the names to show the opinions of the participants. In addition, 5 opinion leaders from the Roma community in Balıkesir also supported the interviews concerning the employment situation of Roma youth.

\subsection{Data collection tool}

In this study, in-depth interview technique, one of the basic tools of qualitative research, based on the interaction and trust relationship between the interviewer and the interviewee, was used to understand how Roma youth experienced the employment process. Apart from face-to-face in-depth interviews, an unplanned focus group interview was held with four of the young participants. The focus group interview offered young participants the opportunity to respond more comfortably, especially in expressing their experiences of exclusion. Apart from the in-depth interview and focus group, the observation notes of the SIROMA4 Project were also used to strengthen the validity of the findings.

\subsection{Data collection process}

A semi-structured interview form was applied to the participants in the data collection process. In the form, questions about employment were asked in three stages. The first stage is related to the job search and job application process. The second stage is focused on experiences in the process of working in any job. At the last stage, the process of quitting the job has been evaluated. In addition, all questions regarding employment were asked by correlating them with the neighborhood and Roma identity.

4 SIROMA: "Technical Assistance for Promoting Social Inclusion in Places Densely Populated by the Roma", funded by the European Union in 2017 and the Republic of Turkey in 2017. It started in 12 provinces, 20 counties by the Ministry of Family and Social Policies of that time on 8 November 2015, and finished on 8 November 2017, is a comprehensive project. Reference Number: EuropeAid/134662/IH/SER/TR. The author of this article was the provincial coordinator of Balıkesir in the period January-November 2017 and participated in field research in different Roma districts at the provincial level. 
The data collection process was carried out from 4-11 July 2019. Before the interviews, the opinion leaders living in the neighborhoods were contacted and the trust relationship was established with the young participants. Places where young participants could feel comfortable were preferred during the interviews. Interviews took place in different locations in the neighborhood and city center. Each interview lasted 30-60 minutes on average. During the interview, a voice recorder was used with the permission of the participants. The interviews were conducted in line with ethical principles and with an approach away from expressions that would offend the participants.

\subsection{Data analysis}

The data collected from the participants was deciphered and analyzed through the qualitative data analysis software Maxqda. The software enables coding between the data of the interview and understanding the relations between these codes. During the coding process of the data, two main themes emerged: "sense of exclusion" and "neighborhood effect". The first one shows what the Roma identity means for the participants in the employment process, and the second shows how the neighborhood as a stigmatized space negatively affects the employment process of the participants.

\subsection{Limitations of research}

The first limitation of the research is spatial. The interviews were carried out in three neighborhoods where Roma live densely in the center of Balıkesir. The second limitation is related to the scope of the subject. This study only focuses on the experience of exclusion phenomenon in the employment process. The third limitation is about the participants. The process of persuading the participants was challenging. Some young Roma refused to the interview because they thought it was unimportant. The fourth limitation concerns the number of participants. The number was limited because it was a qualitative research study and many similar reports were included in the literature. Besides, the interview and observation data obtained from field interviews during the SIROMA Project process were also used to support the opinions of participants. The final limitation of the research concerns an ethical issue. During the interviews, insulting statements based on stereotypes were avoided. The position of the researcher in Roma studies is a critical threshold 5 that can directly affect the relationship with the participants.

\section{Findings}

The main problems faced by Roma community in Turkey are collected in education, housing, health, employment and social services categories. Among the problems, participation in employment is of key importance. This study, through the findings reached by using qualitative research design, has tried to understand in what jobs Roma youth are working and what problems they experience in the job application process and working life.

\subsection{Employment opportunities for Roma}

There is no concrete data on the employment status of Roma. Because the employment data in Turkey cannot be collected based on ethnicity (European Roma Rights Centre, 2014: 21;

\footnotetext{
5 Weckman (2013: 3-12) gives advice to researchers working with Roma/Gypsies. She provides highly guiding methodological principles to tolerate problems that may arise from the researcher's position in the research process.
} 
İlik, 2016: 40). However, with the initiatives of the Ministries of the Republic of Turkey, the European Union and domestic and international NGOs, Roma's issues have begun to be discussed at least in the political level over the last ten years. Although the region, participant profile, time period and methods differ in the studies, the results are similar. Many studies categorize Roma as poor or subclass in terms of income level. Even if the figures are not officially known, Roma remain weak in formal employment in cities.

Many reports and academic studies indicate that Roma are often forced to work in informal and low-paid jobs, with irregular incomes, unqualified (unskilled) positions; and in parttime, low prestigious, precarious, temporary, unhealthy, risky, backbreaking, marginal, informal jobs $^{6}$. Some of the Roma citizens carry on traditional work from the family such as musicianship, floristry, basketry, broom-making, blacksmithing, tin-making, potting, sieve making. Traditional jobs, also called "Roma jobs", vary regionally. Among Roma, while a certain number of people earn their living through periodical/seasonal agricultural and factory works, a large majority work in informal daily jobs. "Marketing, waste collecting, scraping, peddling, cleaning, chauffeuring, carting, porterage, shoe-shining, leather-making" are the most preferred of these daily works. There are also marginal jobs that are not common, such as "fortune-telling and begging". According to the findings obtained from the interviewees, the work done by the Roma youth in Balıkesir, partly matches the general classification above. These jobs can be classified as formal jobs, traditional family jobs and temporary/precarious jobs. The diversity of jobs in the employment process varies according to the profile of the neighborhood, family relations, educational level, the impact of the social surrounding and individual approaches.

\subsection{Roma youth in formal jobs}

Among the interviewees, there are young Roma who achieved to participate in formal jobs such as cashier, worker (supported by İŞKUR7), chef, security guard and hairdresser. There are factors such as "family encouragement, role model leadership and a high level of education" at the background of this participation in regular jobs. One of the interviewees (P6) who is a chef stated that he had, by chance, been involved in a public training course and, after his individual efforts, had been cooking in a hotel for 9 years. The factor that influences the employment of Roma youth is the periodic vocational training courses in the neighborhood ${ }^{8}$. Some opinion leaders underlined that although ISSKUR offered some opportunities to young Roma in neighborhoods, they did not want to work. The young Roma do not accept because the "Community Benefit Programs"9 supported by ISSKUR are limited to periods of 6-9 months. Some young Roma stated that "On-the-Job Training Programs" 10 are more beneficial for them, but this time the employers did not accept them because of their Roma identity.

\footnotetext{
${ }^{6}$ See (Aile ve Sosyal Politikalar Bakanlı̆̆ı, 2017: 126; Akkan et al., 2011: 25; Gün, 2016: 43; İlik, 2016: 40; Marsh, 2008: 55; Romanlar Federasyonu, 2017: 25; Taylan \& Barış, 2015: 25).

7 Turkish Employment Agency (İŞKUR) depends on the Ministry of Family, Labour and the Social Services and it is a public institution established to assist in the protection, development, dissemination and prevention of unemployment and to carry out unemployment insurance services.

8 Through these courses, not only Roma young people but also individuals of different age groups receive training on different fields.

9 İŞKUR implements this program to ensure their adaptation to the labour market and to provide temporary income support. Aim of the program is to prevent the unemployed who have difficulties in their employment and to prepare them to labour market.

${ }_{10}$ This is the program organized for the unemployed registered to ISSKUR to gain professional experience and to see the practice in the occupations they receive theoretical training and to ensure their adaptation to
} 
There is also an interviewee ( $\left.\mathrm{P}_{7}\right)$ who set up his own business as a hairdresser. According to him the young Roma who go to an Apprenticeship (vocational) Training Center with the guidance of family members at an early age can join the employment by setting up their own businesses. Among Roma youth, some of them do not give up applying to the "insured" jobs, although they are usually unemployed. A young Roma emphasized that when he was unemployed, he worked in the bazaar, but it was more important for him to have an "insured" job ( $\left.\mathrm{P}_{3}\right)$.

\subsection{Roma youth in temporary works}

The number of the young Roma working in temporary jobs without social insurance is also high in the neighborhoods. The characteristics of temporary/informal jobs differ in terms of neighborhoods. The young Roma in the Dinkçiler neighborhood tend to be musicians. This neighborhood is known for its "musicians" in Balıkesir. Because of this characteristic, they separate themselves against other Roma neighborhoods by considering themselves as more "prestigious". Most of the families in the neighborhood live on musicianship. The musician profession is transferred from father to son. Traditional transference within the family may adversely affect the motivation of children in education at an early age. Musician families mention that they have serious problems in employment. An interviewee summarizes the situation such as;

"We love this job, we took it from the father but there is no insurance" (P1).

In the neighborhood, adult musicians train the enthusiastic young Roma by including them in their social networks. Although there are good examples of musicianship (such as Hüsnü Şenlendirici, one of the famous Roma musicians in Turkey), it is a daily-job with no insurance. In the employment process, the relationship that young Roma have with a musician job often remains as an "additional" job. Of course, many young Roma declare they want to work in insured jobs with a regular income.

Some young Roma in temporary jobs in the Gümüşçeşme neighborhood, work in the bazaar. The reason the bazaar job is widespread among the young Roma is that the shopkeepers in the neighborhood provide job opportunities for them. One participant stated that when he could not find a job in the market, he turned to the bazaar, which he defined as a "father profession". Women particularly prefer cleaning jobs that have a high risk of physical dangers. In the neighborhood, "süpürgecilik" (broom making) (P10) and "elekçilik" (sieve making) are also common, partly as traditional family occupations. There is also shoe-shiner, waste collector and junk-dealer ( $\mathrm{P} 2)$ among the Roma youth in the Gümüşçeşme neighborhood. Broom making is the main source of livelihood in the Burhaniye neighborhood in the Susurluk district of Balıkesir.

Seasonal jobs in the coastal and inland areas of Balıkesir are also common among Roma youth. There are also families who migrate seasonally to different regions of Turkey in agriculture. The relationship of Roma in seasonal agricultural work leads to a breakdown in the education of school-age children. In the summer, basketry is a traditional business in coastal areas. Especially in Erdek and Edremit, selling chaise lounges and "hawking" jobs are also common among young Roma.

the working environment. It is a program in which the unemployed can improve their professional skills and gain experience. 


\subsection{Exclusion in employment: Job application and working process}

So, which problems do Roma youth experience in the employment process? In this study, it has been seen that there are two phases of employment as "job application" and "working" process which are important for Roma youth.

\subsubsection{Job application}

Social exclusion in cultural, economic and political spheres is the opposite of social integration or, more broadly, inclusion. The term refers to the social conditions and processes that are theoretically complex, ambiguous and flexible (Silver, 1994: 536). Exclusion signifies any disadvantaged situation that a group of people experience individually or as a group within the community they live in (Gezgin, 2016: 73). The disadvantaged situation caused by exclusion leads to the isolation of individuals from various spheres of the social world (social, economic, political, cultural, and spatial) both physically and psychologically. The young Roma pointed out that they were exposed to social exclusion especially in job applications because of their ethnic identity. The phenomenon that triggers and embodies exclusion in job applicants is the identity of the neighborhood.

Most of the Roma communities live in the peripheral or segregated neighborhoods of the cities because of socio-economic reasons. These neighborhoods are not only stigmatized by poverty but also by criminal phenomenon such as crime and drugs. It is possible to come across such stigmatized neighborhoods/territories segregated based on ethnicity or socio-economic status in each city. These places, also known as "Gypsy/Roma neighborhoods" (Açıkalın \& Şahin, 2016: 72) or "exile neighborhoods" (Wacquant, 2014: 120), have a key role in the employment process, especially for the individuals living in it. Therefore, spatial stigmatization (Şentürk, 2015: 176), negatively affects job applications of young people living in these neighborhoods and inhibits the processes of inclusion in the urban area. Some young Roma prefer to keep themselves distant from the neighborhood due to the stigmatized image. They even think about leaving the neighborhood:

"If I were in the money after getting a nice job, the first thing I would do is leave this neighborhood. I am tired of repeating that. Before I began this job, I applied at a super-market. The man (authorized) looked at my CV and saw Gümüşçeşme (name of the stigmatized neighborhood). After that, no one called back." (P3)

One of the young Roma, whose only dream was to be a public officer, accepted the stigmatized image of the neighborhood and preferred to show his address differently in order to hide Roma identity:

"One day, they asked me where I lived in a job application. I told Cengiz Topel [somewhere near Gümüşçeşme neighborhood]. I couldn’t say Gümüşçeşme. But there was a girl working there, the 'devil' and she recognized me. 'Don't you live in the Gümüşçeşme side,' she said. But she didn't let the surrounding people understand the case. The girl was not a Roma, but she said she knew where I really lived because she was also living there." ( $\left.\mathrm{P}_{4}\right)$

Some young Roma who are aware of spatial stigmatization stated that social exclusion is not a problem, especially in metropolitan cities, but that their identity draws attention in smaller cities like Balıkesir $\left(\mathrm{P}_{5}\right)$. Some of them expressed that the employers underlined their neighborhoods in their job application. When they heard the name of the neighborhood, they did not consider young Roma's applications directly or indirectly:

" $10 \%$ of employers evaluate our job applications seriously. The rest do not even care about it. For example, the employer does not say he/she needs it bluntly, but he/she beats around the bush." (P8) 
"I expect them to be clear. When it is said "we have no need for employees" I respect that. Yet, when the name of the neighborhood is mentioned, they beat around the bush, and I don't like it." (P4)

Some young people stated that they received negative answers in their job applications because of health problems and some could not find "references". One of the young Roma especially stated that even "skin color" was a problem in job applications:

"The person sees that we have dark skin. Aha, that's definitely Gypsy, he says. I

clearly feel it. He shakes his head, saying we do not need anyone." (P3)

A certain number of Roma youth who are squeezed between identity and neighborhood in their job application processes are able to fight exclusion. Exclusionary reactions often reduce the motivation of the young Roma in employment. The young Roma prefer to go to "family work" or to the temporary/casual/seasonal jobs mentioned above, considering that it will not make sense to improve their skills. Consequently, social exclusion built on the perception of space and identity in the job application process, prevents the participation of Roma youth in employment and isolates them from formal job opportunities. More importantly, this segregation process strengthens attitudes towards concealing the Roma identity.

\subsubsection{Working life}

The neighborhood, which is described as "wrecked"11 among Roma youth, does not quit following them even after they are employed. The young Roma who succeed in passing the first phase (job application) face a more challenging phase when they start a work. Social exclusion/discrimination against Roma youth continues in working life. In this process, most of the interviewees stated that they were harassed directly or indirectly in their workplaces. Even though they can overcome the employer factor, the relationships with workmates can be nerveracking:

"The biggest problem of our young people at work actually starts after beginning work. When you start chatting with someone then the tension begins. The man asks where you live and insistently asks, when you answer Gümüşçeşme, Gündoğan, then he asks: 'Are you Gypsy?' And then it goes on telling it to the people." (Opinion leader, male, driver, age: 39 )

"When I start to work anywhere, at first it is not a problem in which neighborhood I live. But in time, the people around are starting to talk about my identity allusively." (P8)

A common opinion among Roma youth in the process of working is that exclusion has been overcome in time:

"There are generalizations about Roma in society. I'm very uncomfortable with this. People have prejudices. I have had patience. I worked in harmony with others. I proved myself in the workplace. I gave information about the Roma to everyone I chatted to." (P6)

In the process of working, Roma youth have to struggle with the negative perception created against them. The reaction of Roma youth to social exclusion in the work process is categorized in three ways; "Abandonment", "Disregard" and "Hiding identity". Some young Roma do not receive the exclusionary attitudes of workmates favorably in the workplace. They are getting

${ }^{11}$ The definitions in other countries are as follows: ghetto in the USA, banlieue in France (suburban), quartieri periferici (or degradati) in Italy, problemområde in Sweden, favela in Brazil, villa miseria in Argentina (Wacquant, 2010: 1), varoş (outskirt) or gecekondu (slum) in Turkey. 
stressed in time. So, they react more severely to the others and finally quit the job. Some young people do not care about employer or workmate's mobbing. And also, if some young Roma think their identity will be a problem in the places where they work, they try to keep their identity as confidential as possible.

\subsection{Strategies against exclusion in the triangle of identity, education, and space}

Identity and space are the critical phenomena that affect the process of participation of Roma youth in employment. The balance between identity and space is directly related to the extent to which young people are involved in the educational process. Within this framework, the attitudes of Roma youth according to their educational level were classified in three different ways:

Roma youth with a high level of education: Among Roma youth, some continue to live by hiding their identity, while others emphasize and struggle for Roma identity. Young Roma develop strategies against social exclusion in the employment process, such as caring about vocational courses, ensuring continuity in education, proving oneself with personal performances, persisting in insured jobs and contacting with effective references. The role models in the Roma community also strengthen this group's approach to employment. Social participation (inclusion) is high among these young Roma.

Roma youth with a low level of education: Some of them continue with family jobs (musicians). Another group focuses on temporary and informal jobs. These are the ones who are exposed to exclusion, especially in job-application processes, and who have to partially hide their identity. It is possible to group these young people's responses to exclusion into three categories: "abandonment, disregard and hiding of identity". Social participation is on a middle-level among these individuals.

Uneducated group (junk-dealer, waste collectors): They do not care about the exclusion in employment; they just seem to be focused only on saving the day. They do not have any expectations from the labor market. These young Roma have internalized the social exclusion. Levels of isolation and social closure are high among these young Roma and social participation is weak.

It is also possible to categorize the relationship of Roma youth with their neighborhoods and their approaches towards spatial stigmatization as follows:

- Normalization: The first group states that their neighborhoods are stigmatized because of prejudices and stereotypes from the past. Current problems attributed to the neighborhoods are also routinely experienced in other non-Roma neighborhoods. However, the people living in the urban areas just think of the Roma neighborhoods as problematic.

"Prejudice exists for each notion and for everyone. There is not so much discrimination. Of course, there has been a prejudice legated by the elders, but when you meet, sit, eat, and talk with them (non-Roma), prejudice evaporate." ( $\left.\mathrm{P}_{7}\right)$

- Self-criticism: The second group states that some groups living in the neighborhood are responsible for stigmatization. They emphasize that some individuals in their Roma community have had an impact on the transformation of their neighborhood into "restless" spaces. The neighborhood does not seem to be a safe place because of its criminal associations.

"What a poor and pitiful community this is. Because of a few, many people get frustrated. I see why people don't come to this neighborhood because even we are afraid of it. How can they (non-Roma) not be afraid." (P11)

- Departure: The young Roma in the third group accept the negative stigma built on the neighborhood. They want to distance themselves from the neighborhood. They want to move 
from the neighborhood when they have an opportunity. In their opinion, the neighborhood has sunk into crime. They do not wish to live in these neighborhoods, but they have to live there for now.

"If I had money, I would move to a nice neighborhood with my mother. This neighborhood has already been bad. Its charm is lost." (P9)

"I do not have so many friends in this neighborhood. At the first opportunity, I want to move somewhere else but I am here for now because my family lives here." (P4)

As a result, there is a complex sociological process for Roma youth. On the one hand, they are trying to exist in this cycle of poverty, inadequate education and limited employment. On the other hand, they have to struggle with the exclusion and discrimination.

\section{Conclusion}

Roma in Turkey is typically exposed to social exclusion and discrimination because of their ethnic identity. Exclusionary discourse produces social, economic, cultural and spatial problems in everyday life. This study has sought to understand the employment processes in the economic field from the point of view of the young Roma.

Roma identity stands as a barrier for the young Roma because of the social superstitions in employment. Another phenomenon that is an obstacle is the neighborhoods in which they live. For those living in other parts of the city, these neighborhoods are "tumorous" spaces and marginalized with crime. The criminal character of the neighborhood is identified with this Roma ethnicity, and therefore a social stigma built in the form of "Roma/Gypsy neighborhood" has emerged. The neighborhood, as a stigmatized space, reduces the employability of Roma youth and makes their social integration even more problematic. This study has tried to understand the exclusion experiences of the Roma youth who are squeezed between the stigmatized space and the labor market. Participation in employment is a significant social threshold for Roma youth. It provides a public sphere where the young Roma can struggle with the exclusion and the stigmatization.

The Roma/Gypsy community is part of the ethnic diversity in Turkey. In recent years, the problems of the community have started to be discussed at a systematic level through both academic publications and public-NGO projects. On the one hand, the problems caused by social exclusion are handled in all dimensions. On the other hand, it is concentrating on institutional social policies to improve the capacity of the community. Integrative sociological approaches are preferred rather than discriminative ones across the studies conducted on Roma. An expression used in SİROMA Project, summarizes the perspective on different ethnic and social groups in Turkey: "Our difference is our wealth, our unity is our future".

Roma youth try to overcome social, economic and spatial dimensions of exclusion by individual effort. However, there are structural problems that depend on urban policies and city administrators. The institutional approaches towards the areas where Roma inhabit need to change. Most of Roma community seems to be dependent on social aids according to some social policy-makers. As Roma opinion leaders draw attention, these social aids have negative impacts on the community. The continuity of social aids in the neighborhoods also contributes to the reproduction of negative spatial stigmatization over the neighborhoods. This study recommends focusing on education and employment-oriented activities rather than the official social aids. The common proposition of the Roma opinion leaders and employment experts was that "one person must have a regular income in every household". Having a regular income job will increase the school attendance of children in the household. This will also increase the level of literacy and lead to the training of qualified/skilled employees in the labor market. It is obviously essential for the young Roma to have an insured, secured, and regular income job. A stable employment process 
will reinforce their participation in social life. As well, it will provide a public sphere where they can properly deal with exclusion and stigmatization. Otherwise, social exclusion can easily result in introversion or isolation.

\section{Acknowledgements}

This research did not receive any specific grant from funding agencies in the public commercial, or not-for-profit sectors.

The author declares no competing interests.

\section{References}

Açıkalın, N., \& Şahin, B. (2016). "Burada her şey kendiliğinden”: Mersin'de yaşayan Romanlar üzerine alan araştırması ["Everything happens spontaneously here": A case study on Romani communities living in Mersin]. Sosyoloji Dergisi, 36(1), 71-97. https://doi.org/10.16917/sd.11769

Aile ve Sosyal Politikalar Bakanlı̆̆ı. (2017). Siroma Sosyal İçerme kitabı (No. EuropeAid 134662/IH/SER/TR) [Siroma Social Inclusion book]. Retrieved 18 August 2019, from http://www.ikg.gov.tr/romanlarin-yogun-olarak-yasadigi-alanlarda-sosyal-icermenindesteklenmesi/.

Akkan, B. E., Deniz, M. B., \& Ertan, M. (2011). Sosyal dışlanmanın Roman halleri [Roma states of social exclusion]. İstanbul: Edirne Roman Derneği: Sosyal Politika Forumu: Anadolu Kültür.

Aksu, M. (2010). Türkiye'de Çingene olmak [Being Gypsies in Turkey]. Ankara: Anekdot Yayınevi.

Aras, T. (2016). Çoklu kültürün bir ifade biçimi olarak Çalgıcı Romanlar [Instrumental Roma as a form of expression of multiple cultures]. In P. Yazgan \& F. Tilbe (Series Eds.), Türk Göçü 2016 Seçilmiş Bildiriler-1 (pp. 151-157). Retrieved 2 October 2018, from https://www.researchgate.net/publication/322387169_Coklu_Kulturun_Bir_Ifade_Bicimi_ Olarak_Calgici_Romanlar.

Batı Karadeniz Kalkınma Ajansı. (2016). Sosyal dışlanma sorunsalı ve Zonguldak Roman araştırması [Social exclusion problem and Zonguldak Roma research]. Retrieved 21 January 2020, from https://www.bakkakutuphane.org/dokuman/sosyal-dislanma-sorunsali-ve-zonguldakroman-arastirmasi/239.

Creswell, J. W. (2012). Educational research: Planning, conducting, and evaluating quantitative and qualitative research (4 ${ }^{\text {th }}$ Ed.). Boston: Pearson.

Genç, Y., \& Taylan, H. H. (Eds.) (2017). "Hep Birlikte Daha Güzel Yartnlara”: Proje sonuç raporu ve Roman sorunları alan araşttrması ["Together to a Better Tomorrow": Project final report and field research on Roma issues]. Kocaeli: Bolu Sosyolojik Araştırma Merkezi Derneği.

Gezgin, E. (2016). Damgalanan mekânda yaşam: Bir kentin "öteki’si olmak" [Life in the stigmatized space: Being the "other" of a city]. Ankara: Phoenix Yayınevi.

Gün, S. (2016). Etnikleşen yoksulluk: Çingeneler/Romanlar örneği Ethnicization of poverty: The case of Gypsies/Roma] (Unpublished master's thesis). Hacettepe Üniversitesi, Ankara.

İlik, B. (2016). Türkiye'de Roman yurttaşlarm sorunları ve çözüme ilişkin çalışmalar [The problems of Roma citizens in Turkey and work for solutions]. Retrieved 21 January 2020, from https://docplayer.biz.tr/49068264-Turkiye-de-roman-yurttaslarin-sorunlari-ve-cozumeiliskin-calismalar.html.

Karan, U. (2017). Görmezlikten gelinen eşitsizlik: Türkiye'de Romanların barınma ve eğitim hakkına erişimi [Ignored and unequal: Roma access to the right to housing and education in Turkey]. Retrieved 2 October 2019, from Minority Rights website: http://minorityrights.org/publications/gormezlikten-gelinen-esitsizlik-turkiyederomanlarin-barinma-ve-egitim-hakkina-erisimi/. 
Kenrick, D. (2007). Historical dictionary of the Gypsies (Romanies) (2 ${ }^{\text {nd }}$ Ed.). Lanham, Md: Scarecrow Press.

Kolukırık, S. (2004). Aramızdaki yabancı: Çingeneler [The stranger among us: Gypsies] (Unpublished doctoral dissertation). Ege Üniversitesi, İzmir.

Marsh, A. (2008). Eşitsiz vatandaşlık: Türkiye Çingenelerinin karşılaştığı hak ihlalleri [Unequal citizenship rights violations faced by Gypsies in Turkey]. In E. Uzpeder, S. Danova/Roussinova, S. Özçelik, \& S. Gökçen (Eds.), Biz buradayız! Türkiye'de Romanlar, ayrımcı uygulamalar ve hak mücadelesi. İstanbul: Mart Matbaacılık.

Patton, M. Q. (2002). Qualitative research \& evaluation methods ( $3^{\text {rd }}$ Ed.). Thousand Oaks, Calif.: Sage Publications.

Roman Vatandaşlara Yönelik Strateji Belgesi (2016-2021) [Strategy Document for Roma Citizens] (2016, April 30). Retrieved 18 August 2019, from Resmi Gazete website: http://www.resmigazete.gov.tr/eskiler/2016/04/20160430-11.htm.

Romanlar Federasyonu (2017). Roman İstihdam ve Mesleki Danışmanlık Ağı Projesi: Roman istihdamında bölgesel sorunlar eylem planı [Roma Employment and Vocational Counseling Network Project: Regional problems in Roma employment action plan]. Retrieved 25 August 2019, from IKG website: https://mistik.ikg.gov.tr/upload/2017-09/48e154do-471f-411490ab-e63b892f5f46.pdf.

Şanlıer, S. (2013). Hukuki düzenlemeler ışığında Osmanlı Çingeneleri [Ottoman Gypsies in the light of legal regulations]. İstanbul: Ofis Yayın Matbaacılık.

Şentürk, M. (2015). Dışarıda ve dışında olmak: Yoksul gençlerin mekânla ilişkileri [Being outside and apart: Impoverished youths' relations with locales]. Sosyoloji Dergisi, 3(31), 169-203. https://doi.org/10.16917/sd.04346

Silver, H. (1994). Social exclusion and social solidarity: Three paradigms. International Labour Review, 133(5-6), 531-578. Retrieved 19 August 2019, from https://www.researchgate.net/publication/247563087_Social_Exclusion_and_Social_Solid arity_Three_Paradigms

Taylan, H. H., \& Barış, İ. (2015). Romanlar ve sosyal dışlanma [Roma and social exclusion]. Konya: Çizgi Kitabevi.

Taylan, H. H., Barış, İ., \& Genç, Y. (2015). Sakarya'da Romanlara yönelik sosyal mesafe araştırması [Social distance research for Roma in Sakarya]. In E. Dömek \& H. H. Taylan (Eds.), Uluslararası Roman sorunları çalıştayı bildiri kitabı (pp. 36-43). Retrieved 25 August 2019, from https://www.researchgate.net/publication/310463130_SAKARYA'DA_ROMANLARA_YON ELIK_SOSYAL_MESAFE_ARASTIRMASI.

Türkiye Avrupa Roman Hakları Merkezi Raporu [Turkey and the European Roma Rights Center Report] (2014, March 26). Retrieved 20 January 2020, from European Roma Rights Centre website: http://www.errc.org/reports-and-submissions/turkiye-ulke-profili-2011-2012.

Wacquant, L. (2010). Urban outcasts: A comparative sociology of advanced marginality. Cambridge: Polity Press.

Wacquant, L. (2014). Neoliberal şehirde marjinallik, etnisite ve cezalandırma: Analitik bir kartografya [Marginality, ethnicity and punishment in the neoliberal city: an analytical cartography]. In S. Torlak \& Ö. Kulak (Trans.), Mekan meselesi. İstanbul: Tekin Yayınevi.

Weckman, S. (2013). Researching Finnish Gypsies: Advice from a Gypsy. In D. Tong (Ed.), Gypsies: An interdisciplinary reader (pp. 3-10). New York: Routledge. 